\title{
Escherichia coli strains colonising the gastrointestinal tract protect germfree mice against Salmonella typhimurium infection
}

\author{
S Hudault, J Guignot, A L Servin
}

\begin{abstract}
Background-Escherichia coli is part of the normal gastrointestinal microflora which exerts a barrier effect against enteropathogens. Several $E$ coli strains develop a protective effect against other Enterobacteriaceae.

Aims-Two $E$ coli strains, EM0, a human faecal strain, and JM105 K-12 were tested for their ability to prevent in vivo and in vitro infection by Salmonella typhimurium C5.

Methods-Inhibition of C5 cell invasion by $E$ coli was investigated in vitro using Caco-2/TC7 cells. The protective effect of $E$ coli was examined in vivo in germfree or conventional $\mathrm{C} 3 \mathrm{H} / \mathrm{He} /$ Oujco mice orally infected by the lethal strain C5.

Results-EMO expresses haemolysin and cytotoxic necrotising factor in vitro. In vitro, the two strains did not prevent the growth of C5 by secreted microcins or modified cell invasion of C5. In vivo, establishment of EM0 or JM105 in the gut of germfree mice resulted in a significant increase in the number of surviving mice: $11 / 12$ and 9/12, respectively, at 58 days after infection $\left(2 \times 10^{6} /\right.$ mouse) versus $0 / 12$ in control germfree group at 13 days after infection. Colonisation level and translocation rate of $\mathrm{C} 5$ were significantly reduced during the three days after infection. In contrast, no reduction in faecal C5 excretion was observed in $\mathrm{C} 5$ infected conventional mice $\left(1 \times 10^{8} /\right.$ mouse) receiving the EM0 or JM105 cultures daily. Conclusions-Establishment of $E$ coli strains, which do not display antimicrobial activity, protects germfree mice against infection and delays the establishment of $\mathrm{C} 5$ in the gut. Possible mechanisms of defence are discussed. (Gut 2001;49:47-55)
\end{abstract}

Institut National de la Santé et de la Recherche Médicale, Unité 510, Faculté de Pharmacie Paris XI, 92296

Châtenay-Malabry,

France

$S$ Hudault

J Guignot

A L Servin

Correspondence to: $S$ Hudault.

sylvie.hudault@cep.u-psud.fr

Accepted for publication 19 December 2000

The normal resident intestinal microflora major factor protecting animals and humans against intestinal colonisation by pathogenic bacteria. ${ }^{12}$ In rare cases it has been possible to isolate the bacterial species responsible for protection and to elucidate the mechanism of protection. Escherichia coli is one of the first bacterial genera, along with Streptococcus, to colonise the intestine of human ${ }^{3-6}$ and animal newborns, including mice, rats, piglets, and chickens. It has been reported that several $E$ coli strains develop a protective effect against antibiotic resistant, colicin sensitive, and enterotoxigenic $E$ coli. ${ }^{7-13}$ Barrow and Tucker $^{14}$ demonstrated strong inhibition of intestinal colonisation of chicken caecum with Salmonella typhimurium by pretreatment ( 24 hours before) with strains of three $E$ coli strains but the strains were not equally effective against other strains of Salmonella.

Here we examined the efficacy of an $E$ coli K-12 JM105 strain and a human faecal $E$ coli strain, EM0, against $S$ typhimurium infection in mice and in vitro in human cultured cells. Salmonella can be divided in two groups-those that typically produce typhoid-like infections in humans or animals and those that produce non-life threatening gastroenteritis (food poisoning). The severity of the disease depends on the serovar and the host. In nearly all Salmonella infections, the bacteria multiply in the lumen in the small intestine, rapidly penetrate the intestinal mucosa, and reach the mesenteric lymph nodes (MLN) where they multiply. Most infections do not proceed beyond the local lymph nodes. Some more invasive strains can spread into the circulatory system and to deeper tissue such as the spleen and the liver. Infected bile causes a secondary intestinal infection and leads to the carrier state. $^{15}$ In mice, $S$ typhimurium induces typhoid-like disease and its primary site of invasion is the terminal ileum. ${ }^{16}{ }^{17}$ Peyer's patches and $M$ cells of the small intestine are the first to be invaded ${ }^{18}$ allowing the Salmonella to reach the MLN, and then the spleen and the liver. ${ }^{16}$ It is known that mouse genotype plays a critical role in the sensitivity to the lethal effect in systemic salmonellosis induced by $S$ typhimurium. We have chosen $\mathrm{C} 3 \mathrm{H} / \mathrm{He} / \mathrm{Oujco}$ mice which have the same characteristics as $\mathrm{C} 3 \mathrm{H} / \mathrm{He}$ mice. This breed ${ }^{19}$ is resistant to $S$ typhimurium C5 given subcutaneously $\left(\mathrm{LD}_{50}>10^{5}\right)$. We observed that germfree $\mathrm{C} 3 \mathrm{H} / \mathrm{He} / \mathrm{OuJI}$ co mice died in approximately eight days after oral infection by $2 \times 10^{6}$ bacteria/mouse whereas their conventional counterparts survived. ${ }^{20}$

The $E$ coli strain EM0 was originally isolated from the faecal flora of a healthy human volunteer. ${ }^{9}$ It has been shown to have a protective
Luria-Bertoni broth; hlyA, $\alpha$-haemolysin; cdt, cytolethal distending toxin; PBS, phosphate buffered saline; TSA, tryptic soy agar; SS agar, Shigella and Salmonella agar; PCR, polymerase chain reaction; necrotising factor; MLN, mesenteric lymph nodes; IL, interleukin; TNF- $\alpha$, tumour necrosis factor $\alpha$.
Abbreviations used in this paper: $\mathrm{LB}$ broth, $\mathrm{LDH}$, lactate dehydrogenase; CNF, cytotoxic 
effect against establishment of $E$ coli antibiotic resistant strains in germfree mice, ${ }^{9}$ against antibiotic resistant enterobacteria in human newborns, ${ }^{1321}$ and gnotobiotic mice. ${ }^{22}$ It has a protective effect against ETEC K88 in piglets. $^{912}$ The mechanism suggested is either "adaptation" of the EM0 strain inoculated first to germfree mice as ultrastructural differences in cell morphology were observed in vivo but disappeared in in vitro cultures, ${ }^{9}$ or a slower generation time for the resistant enterobacteria mutant. ${ }^{22}$ Moreover, this strain plays a role in the development of the immune system in germfree mice (MC Moreau, personal communication), inducing oral tolerance to ovalbumine ${ }^{23}$ and the production of cytokines in peritoneal and bone marrow macrophages. ${ }^{24} 25$

To investigate the antagonistic activity of the $E$ coli strains against $S$ typhimurium oral infection in vivo, two experimental designs were used: $E$ coli were given to either: (i) germfree animals to study the effect of the extensive gut colonisation by $E$ coli on protection against $S$ typhimurium infection; or (ii) conventional $\mathrm{C} 3 \mathrm{H} / \mathrm{He} /$ Oujco mice to examine if an $E$ coli strain, given daily as a probiotic that can transit along the gut, exerts an antagonistic effect in situ against infecting $S$ typhimurium. In vitro, $S$ typhimurium invades enterocyte-like Caco-2 cells. ${ }^{26}$ We next examined if the $E$ coli strains exerted an antibacterial effect in vitrothat is, whether they could inhibit invasion of cultured human enterocyte-like Caco-2/TC7 cells by $S$ typhimurium.

\section{Methods}

BACTERIAL STRAINS AND GROWTH CONDITIONS The $E$ coli strain EM0 was originally isolated from the faecal flora of a healthy human volunteer $^{9}$ and was kindly supplied by Y Duval (INRA, Jouy-en-Josas, France). The strain $\mathrm{JM} 105^{27}$ is an $E$ coli $\mathrm{K}-12$ strain $^{28}$ kindly provided by $M$ Fons (INRA). $S$ typhimurium strain C5 was kindly provided by $M$ Popoff (Institut Pasteur, Service des Entérobactéries, Paris, France).$^{29} E$ coli strains and $S$ typhimurium C5 were grown in Luria-Bertoni broth (LB) (Difco, Detroit, Michigan, USA) for 18 hours at $37^{\circ} \mathrm{C}$ under aerobic conditions. After centrifugation, the bacteria were resuspended and adjusted to the appropriate concentration in sterile phosphate buffered saline (PBS) for assay. Viable counts of $E$ coli or $S$ typhimurium were obtained after plating suitable dilutions on tryptic soy agar (TSA) (Difco) and incubation at $37^{\circ} \mathrm{C}$ for 18 hours. When differential counts of $S$ typhimurium from $E$ coli were necessary, viable bacteria were enumerated on Shigella and Salmonella agar (SS agar) (Difco). After incubation for $24-48$ hours at $37^{\circ} \mathrm{C}$, colonies of $S$ typhimurium were black and easily distinguishable from $E$ coli colonies or normal resident enterobacteria which gave red or pink colonies.

PCR

Polymerase chain reaction (PCR) detection of $\alpha$-haemolysin (hlyA), cytotoxic necrotising factor 1 and 2 (cnf 1-2), and cytolethal distending toxin $(c d t)$ sequences were performed with gene
Amp PCR system 2400 (Perkin-Elmer Applied Biosystems, Courtabeouf, France). Primers hlyA1 (5'-CTC ATT GGC CTC ACC GAA CGG-3') and hlyA2 (5'-GCT GGC AGC TGT GTC CAC GAG-3') were designed to amplify a $299 \mathrm{bp}$ internal fragment from $h l y A$ gene. Primers cnfA (5'- CTG AGC GGC ATC TAC TAT GAA G-3') and cnfB (5'-CCT GTC AAC CAC AGC CAG TAC-3') were designed to amplify a $626 \mathrm{bp}$ internal fragment from cnf gene. Primers cdt1 (5'- GTW GCR ACY TGG AAY YTK CAR GG -3') and cdt2 (5'-KCM GGY KMR CGR TTR AAA TCW CC -3') were designed to amplify a $500 \mathrm{bp}$ internal fragment from $c d t$ gene. Colony PCR was carried out using "PCR beads ready to go" (Amersham Pharmacia, Saclay, France) according to the manufacturer's protocol. After initial denaturation (five minutes at $94^{\circ} \mathrm{C}$ ), the samples were subjected to 30 cycles of amplification, each of which consisted of the following steps: 30 seconds at $94^{\circ} \mathrm{C}, 30$ seconds at $57^{\circ} \mathrm{C}$, and one minutes at $72^{\circ} \mathrm{C}$. A final extension step of 10 minutes at $72^{\circ} \mathrm{C}$ was conducted. PCR products were examined on $1 \%$ agarose gels. As positive controls, we used $E$ coli SE124 hly ${ }^{+30} E$ coli $\mathrm{J} 96 h_{l y}^{+}$, and cnf $^{+31}$ kindly provided by $\mathrm{P}$ Boquet (Inserm U452, Nice, France), and $E$ coli DH5apOMEO1, ${ }^{32}$ kindly provided by E Oswald (Ecole Nationale Vétérinaire, Toulouse, France).

HAEMOLYSIN ASSAY

For qualitative evaluation of haemolysin production, isolates were inoculated onto Columbia agar plates (Biomérieux, Marcy l'Etoile, France) containing 5\% sheep blood..$^{33}$ Haemolysis was defined as a distinct zone of clearing around and under isolated bacterial colonies after three or 18 hours at $37^{\circ} \mathrm{C}$.

MEASUREMENT OF CELL INTEGRITY AND MULTINUCLEATING EFFECT

Cell integrity was determined by measuring release of lactate dehydrogenase (LDH) from cells in the culture medium (Enzyline LDH kit; Biomérieux, Dardilly, France). Infection was conducted with the bacterial suspension of $E$ coli $\left(1 \times 10^{8} \mathrm{cfu} /\right.$ well $)$ or with the filtered spent culture supernatants $(0.22 \mu \mathrm{m}$ filter unit, Millex GS; Millipore, Saint Quentin, France) $\mathrm{GmbH})$. Aliquots $(20 \mu \mathrm{l})$ of the incubation medium were sampled one, two, three, or four hours after infection. Results are given as percentage $\mathrm{LDH}$ released calculated as follows: $\mathrm{LDH}$ release (UI) found in test well/LDH release (UI) found in control well after cell lysis with distilled water (3000 UI). Assays were run at least in triplicate for three successive cell passages. Multinucleating effect due to $\mathrm{CNF}$ was studied on HeLa cells and on Caco-2/TC7 cells, as described by de Rycke and colleagues. ${ }^{34}$ Briefly, a $100 \mu 1$ volume of a cell suspension containing $4 \times 10^{4}$ cells $/ \mathrm{ml}$ (HeLa cells) or $6 \times 10^{4} / \mathrm{ml}$ cells (Caco-2/TC7 cells) was distributed in culture cell well plates (Corning Glass Works, Corning, New York, USA) with a glass coverslip, and $22.5 \mu \mathrm{l}$ of a fourfold dilution of the bacterial extracts in PBS was added. The multinucleating effect was observed after 72 hours of incubation after the 
cells were stained (Giemsa stain) by light microscopy (Leica Aristoplan, RueilMalmaison, France).

CELL CULTURE

The cultured Caco-2/TC7 clone cells ${ }^{35}$ established from the parental human colonic adenocarcinoma Caco-2 cell line ${ }^{36}{ }^{37}$ were used. Cells were routinely grown in Dulbecco's modified Eagle's minimal essential medium (25 mM glucose) (Eurobio, Paris, France), supplemented with $10 \%$ inactivated fetal calf serum (Boehringer, Mannheim, Germany) and 1\% non-essential amino acids. For inhibition of cell association and cell invasion of $S$ typhimurium, monolayers of Caco-2/TC7 cells were prepared in six well Corning tissue culture plates (Corning Glass Works). Cells were seeded at a concentration of $1.4 \times 10^{4}$ cells $/ \mathrm{cm}^{2}$. Maintenance of cells and all experiments were carried out at $37^{\circ} \mathrm{C}$ in a $10 \% \mathrm{CO}_{2} / 90 \%$ air mixture. The culture medium was changed daily. Cells were used at late post confluence-that is, after 15 days in culture. HeLa cells were cultured at $37^{\circ} \mathrm{C}$ with $5 \% \mathrm{CO}_{2}$ in RPMI 1640 with $2 \mathrm{mM}$ L-glutamine (Life Technologies, CergyPontoise, France) supplemented with 10\% inactivated fetal calf serum.

INFECTION OF CACO-2/TC7 CELLS

The cell infection assay was conducted as previously reported. ${ }^{38}$ Briefly, prior to infection, the Caco-2/TC7 monolayers were washed twice in PBS. Monolayers were then incubated for 15-30 minutes with PBS before infection. A suspension of $2 \times 10^{8} \mathrm{cfu} / \mathrm{ml}(0.5 \mathrm{ml})$ of bacteria in PBS and $0.5 \mathrm{ml}$ of the cell culture medium (containing $1 \%$ mannose to prevent pili-1 mediated adhesion) were added to each well of the tissue culture plate. The plates were incubated for different times at $37^{\circ} \mathrm{C}$ in $10 \%$ $\mathrm{CO}_{2} / 90 \%$ air and washed three times with sterile PBS. S typhimurium internalisation was determined by quantitative determination of bacteria located within the infected monolayers using the aminoglycoside antibiotic assay. After one hour of infection, monolayers were washed twice with sterile PBS and incubated for 60 minutes in medium containing $100 \mu \mathrm{g} / \mathrm{ml}$ of gentamicin to kill extracellular bacteria. The monolayers were washed three times with PBS and lysed with sterilised distilled water. Appropriate dilutions were plated on SS to determine the number of viable intracellular bacteria by bacterial colony counts. Assays were conducted several times with three successive passages of Caco-2/TC7 cells.

INHIBITION ASSAY OF $S$ TYPHIMURIUM ENTRY WITHIN CACO-2/TC7 CELLS

Inhibition of $S$ typhimurium $\mathrm{C} 5$ cell invasion by $E$ coli was determined as follows: $S$ typhimurium $\left(1 \times 10^{8} \mathrm{cfu} / \mathrm{ml}\right)$ suspended in PBS with the $E$ coli strain in its supernatant $\left(1 \times 10^{8} \mathrm{cfu} / \mathrm{ml}\right)$ were added to each Caco-2/TC7 culture well for one hour at $37^{\circ} \mathrm{C}$. For the EM0 strain, the experiment was conducted in the presence of dextran 4 (Sigma) at a final concentration of 30 $\mathrm{mM}$ for osmotic protection against the pores induced by $E$ coli EM0 haemolysin, ${ }^{39}$ for one hour at $37^{\circ} \mathrm{C}$. Control experiments were conducted with PBS, pH 7. Determination of viable intracellular $S$ typhimurium was conducted as described above.

DETECTION OF ANTIBACTERIAL ACTIVITY

Detection of colicin was performed as previously described. ${ }^{11}$ Briefly, aliquots of 12 hour cultures of $E$ coli EM0 or JM105 were placed on hydrophobic membranes $(0.45 \mu \mathrm{m})$ (HGMF QA Life Science Inc., San Diego, USA) which were themselves placed on brain heart infusion agar plates (Difco). After incubation for 24 hours at $37^{\circ} \mathrm{C}$, membranes were removed and plates were overlayed with $10 \mathrm{ml}$ of agar. This overlay agar consisted of minimum medium containing $6 \mathrm{~g} / 1$ of agar, inoculated with a fresh overnight culture of $S$ typhimurium C5. After incubation for 18-24 hours at $37^{\circ} \mathrm{C}$, the clear zone surrounding the membranes indicated the presence of antibacterial compounds. Co-culture of $S$ typhimurium C5 and E coli strains EM0 or JM105 were performed by incubating approximately $1 \times 10^{8}$ $\mathrm{cfu} / \mathrm{ml}$ of each bacteria at $37^{\circ} \mathrm{C}$ in $\mathrm{LB}$ broth. Initially, and at predetermined intervals, aliquots were removed, serially diluted, and plated on SS agar to determine bacterial colony counts, as described above.

MICE

Both germfree (Cesal, Orléans, France) and conventional mice (Iffa Credo, L'Arbresle, France) were adult female $\mathrm{C} 3 \mathrm{H} / \mathrm{He} / \mathrm{Oujco}$ mice, 7-8 weeks of age. They were housed, fed, and sacrified in accordance with the highest standards of humane animal care and the relevant national legislation. Germfree mice were reared in Trexler type isolators fitted with a rapid transfer system (La Calhène, Vélizy Villacoublay Cedex, France). Germfree mice were checked for freedom from bacterial contamination by culture of fresh faeces aerobically and anaerobically. They were given ad libitum a commercial diet RO3 40 (UAR, Villemoisson/Orge, France) sterilised by gamma irradiation (40 kGy) and autoclaved demineralised water. Conventional mice were fed an identical but not sterile diet.

\section{INFECTION OF MICE}

Germfree mice were infected orally by drinking a Salmonella suspension in bottled water. Animals were deprived of water from the day before. Each mouse drank approximately $5 \mathrm{ml}$ of the suspension containing $4 \times 10^{5} \mathrm{cfu} / \mathrm{ml}$ (that is, approximately $2 \times 10^{6} \mathrm{cfu} /$ mouse) within a few hours. This protocol was used to avoid the risks of injuring with an intragastric gavage needle (difficult to manage in isolators) and oral and systemic inoculation. E coli EM0 or JM105 strains were inoculated in germfree mice in a similar manner as that for Salmonella. Where the effect of colonisation of $E$ coli on establishment of C5 was studied, Salmonella was inoculated seven days after $E$ coli inoculation. Germfree mice infected by one strain only, Salmonella or $E$ coli, were termed monoassociated mice. Diassociated mice harboured two bacterial strains $(E$ 
coli and Salmonella). Mono or diassociated germfree mice were termed gnotobiotic mice.

Conventional mice were infected intragastrically via a gavage needle. On day 0 , mice received either $0.2 \mathrm{ml}$ of LB broth (control) or $0.2 \mathrm{ml}$ of $E$ coli culture (assay, $10^{8} \mathrm{cfu} /$ mouse). A few minutes later they were infected with a single oral dose of $S$ typhimurium C5 $\left(1 \times 10^{8}\right.$ $\mathrm{cfu} /$ mouse). For seven days after infection of C5, treatment with LB broth or $E$ coli culture was administrated daily at the same dose as on day 0 .

DETERMINATION OF $S$ TYPHIMURIUM OR E COLI IN FAECES AND TISSUES OF MICE

Fresh faecal samples were collected from the anus of each mice. Faecal samples were obtained one, four, and seven days after infection in C5 infected conventional mice. They were collected daily in the case of gnotobiotic mice. Faeces were weighed and diluted 10-fold in PBS. Viable C5 bacteria were determined by plating serial decimal dilutions on SS agar medium (Difco) to differentiate Salmonella counts from those of the resident enterobacteria, as described above. Results are expressed as the mean value of viable Salmonella counts ( $\log \mathrm{cfu} / \mathrm{g}$ of faeces).

Mono or diassociated mice were killed by cervical dislocation. Tissue samples were obtained in the following order: mesenteric lymph nodes (MLN), spleen, and liver. The intestines were unfolded gently to collect MNL and a sterile swab was passed over the intestinal cavity to verify that the intestinal wall had not been damaged. This swab was soaked in $1 \mathrm{ml}$ of PBS which was plated on SS medium. Whenever it proved positive $(>5 \mathrm{cfu} / \mathrm{ml})$, the results of the corresponding mouse for MNL, spleen, and liver were discarded. The different segments were removed in the following order: small intestine (divided into three segments corresponding approximately to the duodenum, jejunum, and ileum) and caecum. In most experiments, only the contents were sampled. However, in one experiment the intestinal wall of the segment was obtained. After removal of the contents, the intestinal wall was gently washed with eight successive $5 \mathrm{ml}$ sterile PBS aliquots and drained before being weighed. All content samples were weighed and diluted 10-fold in PBS. Organs were weighed and homogenised with $2 \mathrm{ml}$ of PBS by Ultraturrax for two minutes and diluted 10 -fold. The number of viable bacteria in the samples was estimated by plating serial decimal dilutions on TSA or SS agar when differential counts of $S$ typhimurium and $E$ coli were necessary. Bacterial counts are given per gram of intestinal wall per organ (MLN, spleen, and liver) or per gram of contents.

STATISTICAL ANALYSIS

Numbers of viable bacteria were compared by variance analysis using the Student's $t$ test. Numbers of surviving mice were compared by the exact Fisher test. ${ }^{40}$

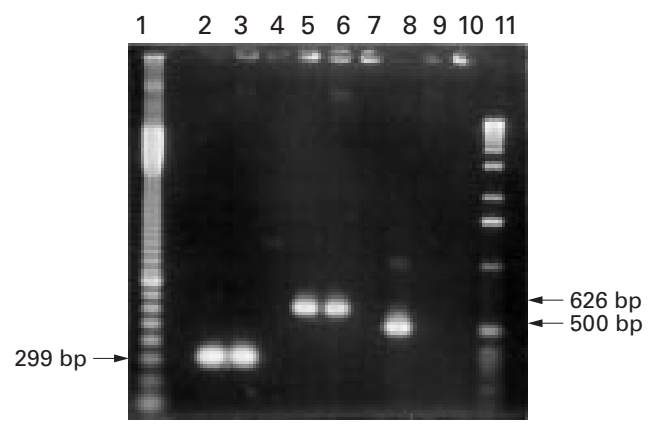

Figure 1 Polymerase chain reaction (PCR) amplification of hly, cnf, and cdt from E coli EMO strain. Lane 1: $100 \mathrm{bp}$ molecular weight marker; lanes 2-4: hly primers; lanes 5-7: cnf primers; lanes 8-10: cdt primers; lane 11: $1 \mathrm{~kb}$ molecular weight markers; lanes 3, 6, and 9: E coli EMO, lanes 4, 7, and 10: E coli $7 M 105$; lane 2: E coli SE124, hly ${ }^{+}$; lane 5: E coli 796, cnf $^{+}$; lane 8: E coli DH5apOMEO1, cdt ${ }^{+}$. The E coli strain EMO showed specific amplification with the hly and cnf primers whereas the $E$ coli $\mathscr{F} M 105$ strain showed no amplification.

\section{Results}

CHARACTERISTICS OF THE E COLI STRAINS

Although the $E$ coli strain EM0 was isolated from the faeces of a healthy human volunteer and was described as a non-pathogenic strain, ${ }^{13}$ we found that it had virulence factor genes such as haemolysin (hly) and cytotoxic necrotising factor (cnf). As shown by PCR (fig 1), the $E$ coli strain EM0 showed specific amplification with the primers hly and cnf as did the positive control E coli strains J96, hly+ and cnft, and SE124, hly+. In contrast, no amplification was found with the cdt primers. In addition, $h l y$, cnf, and $c d t$ were not detected by PCR in E coli JM105 strain.

Functional haemolysin was revealed by observation of blood haemolysis on sheep blood Columbia agar plates. Concurrently, we found that cell lysis developed in EM0 infected Caco-2/TC7 cells. Indeed, cell infection was followed by release of intracellular $\mathrm{LDH}$ in the culture medium which develops as a function of time after infection. In EM0 infected cells at two and three hours after infection, $23(2) \%$ and 98.7 (6)\% of intracellular $\mathrm{LDH}$ was released, respectively. The two positive control E coli strains J96 and SE124 promoted similar $\mathrm{LDH}$ release. Observation of infected cells showed that the monolayers become fragile at one hour after infection and were entirely destroyed at three hours after infection. The culture supernatants of the EM0 strain and the haemolysin positive control strains were inactive, indicating bacterial contact dependent cell lysis.

Cytotoxicity related to CNF has been reported to be characterised by the appearance of multinucleated cells. ${ }^{34}$ In agreement with this, we observed that infection by the $E$ coli strains EM0 and J96 both in HeLa and Caco2/TC7 cells was followed by the appearance of a high level of multinucleated cells (not shown).

ESTABLISHMENT OF E COLI STRAINS IN THE INTESTINE OF MONOASSOCIATED C3H/HE/OUJCO MICE

To study intestinal colonisation in germfree C3H/He/Oujco mice by E coli EM0 and JM105 
Table 1 Translocation and distribution in the gut of E coli 7 M105 or EMO in monoassociated mice

\begin{tabular}{|c|c|c|c|c|}
\hline & \multicolumn{4}{|c|}{ E coli (mean (SEM)) log10 cfu/g of: } \\
\hline & \multicolumn{2}{|c|}{ Intestinal content } & \multicolumn{2}{|c|}{ Washed intestinal wall } \\
\hline & EMO & $f M 105$ & EMO & $f M 105$ \\
\hline $\mathrm{Sil}^{\mathrm{a}}$ & $5.0(0.6)$ & $5.5(0.9)$ & $3.8(0.4)$ & $3.8(0.6)$ \\
\hline $\mathrm{Si} 2$ & $5.9(0.4)$ & $6.8(0.4)$ & $3.8(0.6)$ & $5.6(0.6)$ \\
\hline $\mathrm{Si} 3$ & $7.2(0.6)$ & $8.3(0.3)$ & $5.4(0.5)$ & $7.4(0.3)$ \\
\hline \multirow[t]{2}{*}{ Caecum } & $10(0.2)$ & $10(0.0)$ & $7.6(0.3)$ & $8.4(0.2)$ \\
\hline & \multicolumn{2}{|c|}{ Log10 cfulorgan } & & \\
\hline MLN & $2.2(0.1)^{\star \star}$ & $1.3(0.1)^{\star \star}$ & & \\
\hline Spleen & 0 & 0 & & \\
\hline Liver & 0 & 0 & & \\
\hline
\end{tabular}

${ }^{a}$ The small intestine was divided into three equivalent parts ( $\left.\mathrm{Si} 1, \mathrm{Si} 2, \mathrm{Si} 3\right)$ corresponding approximatively to the duodenum, jejunum and ileum.

MLN, mesenteric lymph nodes.

${ }^{\star} \star$ Significantly different, $\mathrm{p}<0.01$.

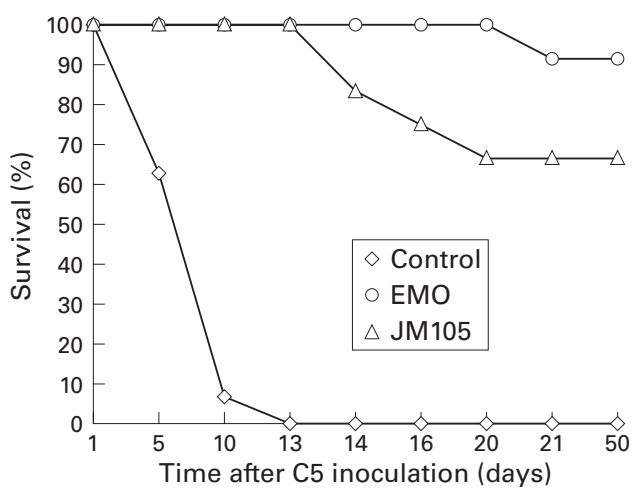

Figure 2 Survival of control germfree mice $(n=12)$ and ex germfree mice monoassociated with $E$ coli $\mathcal{F M} 105$ $(n=12)$ or EMO $(n=12)$, after $S$ typhimurium $C 5$ oral infection. C5 oral infection $\left(2 \times 10^{6}\right.$ cfu/mice) occurred eight days after inoculation of E coli. Significant difference between control germfree group and EMO and FM105 diassociated groups $(p<0.0001)$.

strains, two groups of six mice, reared in separate isolators, received E coli EM0 or JM105 bacteria as a single dose $\left(10^{6} \mathrm{cfu} / \mathrm{ml}\right)$. Each strain became rapidly established in the gut. EM0 and JM105 bacteria were detected at a level of $9.7(0.0)$ and $9.4(0.0)$, respectively, (mean (SEM) $\log 10 \mathrm{cfu} / \mathrm{g}$ of fresh faeces) one day after oral inoculation, and at $10.5(0.1)$ and $10.3(0.1)$ on and after day 2 post inoculation. By day 8 after inoculation, mice were killed and the population levels of E coli EM0 and JM105 were determined in intestinal contents (table 1). The two $E$ coli populations similarly increased from the proximal to the distal intestine. E coli EM0 and JM105 were also detected in MLN at about 100 and 50 bacteria per

Table 2 Comparative kinetics of colonisation of $S$ typhimurium C5 in germfree control mice and in monoassociated mice with E coli EMO or $7 M 105$

\begin{tabular}{lllll}
\hline & \multicolumn{3}{l}{$\begin{array}{l}\text { Salmonella C5 (mean (SEM)) } \\
\text { Days after C5 oral infection }\end{array}$} \\
\cline { 2 - 5 } Germfree mice & 1 & 2 & 3 & 5 \\
\hline $\begin{array}{l}\text { Control group (n=6) } \\
\text { Associated with: }\end{array}$ & $9.1(0.2)$ & $9.5(0.2)$ & $9.8(0.1)$ & - \\
$\quad$ EM0 (n=12) & $6.9(0.1)$ & $7.6(0.1)^{\star \star \star}$ & $8.1(0.1)^{\star \star \star}$ & $9.5(0.1)$ \\
JM105 (n=12) & $7.6(0.1)$ & $9.1(0.2)$ & $9.6(0.1)$ & $9.8(0.2)$ \\
\hline
\end{tabular}

${ }^{\mathrm{a}}$ As the animals were dying, no more faecal samples were obtained at five days.

${ }^{\star} \mathrm{EM} 0$ group significantly different from control group $(\mathrm{p}<0.001)$ on days 1,2 , and 3 after infection; ${ }^{\star \star}$ JM105 group significantly different from control group $(\mathrm{p}<0.001)$ on day 1 after infection; $\star \star \star \star$ significant difference between JM105 and EM0 groups $(\mathrm{p}<0.001)$. organ, respectively, indicating translocation. The number of tissue associated $E$ coli was measured in washed organs. E coli EM0 and JM105 were only partly associated with the mucosa of the gastrointestinal tract of monoassociated mice as the number of associated bacteria was always 10 or 100 times lower. This association on the mucosa increased from the proximal to the distal intestine, as for intestinal contents. The number of $E$ coli in aliquots of the last wash of each organ was always $10^{2}-$ $10^{4}$ times lower than the number of $E$ coli remaining in the washed organ itself. Although the EM0 strain has two specific virulence genes, such as haemolysin and CNF demonstrated by PCR, and shows functional effects in vitro, no adverse effect was observed in germfree mice colonised by this strain in our experimental conditions, as previously reported by others..$^{922}$

EFFECT OF ESTABLISHMENT OF E COLI STRAINS ON THE MORTALITY INDUCED BY $S$ TYPHIMURIUM AND ON INTESTINAL COLONISATION OF $S$ TYPHIMURIUM C5 GERMFREE C3H/HE/OUJCO MICE

We examined the effect of each $E$ coli strain established in the gut of germfree $\mathrm{C} 3 \mathrm{H} / \mathrm{He} /$ Oujco mice on $S$ typhimurium C5 induced mortality. Two groups of 12 germfree $\mathrm{C} 3 \mathrm{H} / \mathrm{He} /$ Oujco mice, reared in separate isolators, were inoculated with EM0 or JM105 E coli. Eight days after $E$ coli inoculation, they were orally infected with $S$ typhimurium strain C5 $\left(2 \times 10^{6}\right.$ $\mathrm{cfu} /$ mouse) and compared with a group of 12 germfree mice infected singly by $\mathrm{C} 5$ under the same conditions. As shown in fig 2, establishment of E coli EM0 or JM105 in germfree mice significantly increased survival of C5 infected mice. Indeed, at 13 days after infection, all diassociated $\mathrm{C} 5$ infected mice survived while all control C5 infected mice were dead $(\mathrm{p}<0.0001)$. The EM0 strain apparently gave better protection than the JM105 strain as 11 of 12 and nine of 12 mice, respectively, survived 58 days post $\mathrm{C} 5$ infection. However, the difference between the EM0 and JM105 groups was not significant.

EFFECT OF ESTABLISHMENT OF E COLI STRAINS ON INTESTINAL COLONISATION OF $S$ TYPHIMURIUM C5 IN GERMFREE C3H/HE/OUJCO MICE.

The kinetics of establishment of $S$ typhimurium in faeces of EM0 or JM105 monoassociated mice (12 per group) were determined and compared with those obtained in the control germfree group (six mice) after infection by $\mathrm{C} 5$ (table 2). On the first day after infection, the level of C5 in faeces was significantly lower in both EM0 and JM105 E coli diassociated groups compared with the $\mathrm{C} 5$ infected germfree control group $(\mathrm{p}<0.0001$ and $\mathrm{p}<0.001$, respectively). Afterwards, the level of $\mathrm{C} 5$ in faeces evolved differently for each group of $E$ coli monoassociated mice. This inhibition was maintained in the EM0 associated group because by day 5 after $\mathrm{C} 5$ infection, the C 5 population level had increased and reached the level observed on day 2 after infection in the germfree infected control group. In contrast, for JM105 associated mice, inhibition was no 
Table 3 Intestinal colonisation and translocation of $S$ typhimurium $C 5$ in germfree mice associated or not with $E$ coli EMO or FM105, three days after C5 infection, and in surviving mice at 58 days after infection

\begin{tabular}{|c|c|c|c|c|c|c|c|}
\hline \multirow[b]{3}{*}{$\begin{array}{l}\text { Germfree mice } \\
3 \text { days after infection }\end{array}$} & \multicolumn{7}{|c|}{ Salmonella C5 (mean (SEM)) } \\
\hline & \multicolumn{4}{|c|}{ Log10 cfu/g of content } & \multicolumn{3}{|c|}{ Log10 cfulorgan } \\
\hline & Sils & $S i 2^{a}$ & $\mathrm{Si}^{b}$ & Caecum $^{d}$ & $M l n^{c}$ & Spleen $^{d}$ & Liver \\
\hline Control group (6) & $3.3(0.5)$ & $5.1(0.2)$ & $6.6(0.2)$ & $9.8(0.1)$ & $5.4(0.3)$ & $3.4(0.2)$ & $3.8(0.1)$ \\
\hline \multicolumn{8}{|l|}{ Associated with } \\
\hline EM0 (5) & $3.6(0.4)$ & $3.6(0.3)$ & $5.1(0.4)$ & $8.3(0.1)$ & $4.2(0.1)$ & $1.4(0.3)$ & $2(0.2)$ \\
\hline JM105 (4) & $3.2(0.8)$ & $4.7(0.6)$ & $4.9(0.4)$ & $8.6(0.1)$ & $4.4(0.1)$ & $1.8(0.3)$ & $2.5(0.2)$ \\
\hline \multicolumn{8}{|c|}{ At 58 days after infection (surviving mice) } \\
\hline EM0 (5) & nd & nd & $5.9(0.5)^{\star}$ & $8.8(0.2)^{\star \star}$ & $2.4(0.5)$ & $2.2(0.3)$ & $3(0.5)$ \\
\hline JM105 (7) & nd & nd & $7.3(0.3)$ & $10.1(0)$ & $2.5(0.4)$ & $2.6(0.4)$ & $3.5(0.7)$ \\
\hline
\end{tabular}

§See legend to table 1 .

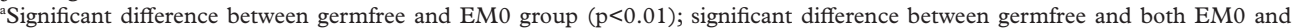
JM105 E coli groups ( ${ }^{b} \mathrm{p}<0.01,{ }^{c} \mathrm{p}<0.001,{ }^{\mathrm{d}} \mathrm{p}<0.0001$, respectively); significantly different from JM105 group ( ${ }^{\star} \mathrm{p}<0.05$ and $\star \star \mathrm{p}<0.001$, respectively).

nd, not done.

longer significant by days 2 and 3 after infection.

The translocation rate and levels of $\mathrm{C} 5$ in the contents of the successive digestive segments were determined in two groups of $E$ coli associated mice and in control germfree mice on day 3 after infection by C5 (table 3). Increasing levels of C5 were found from the Sil segment to the caecum of the control group and from those of the two groups of $E$ coli diassociated mice. However, a significant difference was observed between C5 levels in segments $\mathrm{Si}$ 2, $\mathrm{Si} 3$, and the caecum of EM0 diassociated mice compared with C5 infected control mice. In JM105 diassociated mice, the population level of C5 decreased significantly only in distal digestive segments ( $\mathrm{Si} 3$ and the caecum). The translocation rate of $\mathrm{C} 5$ was lowered significantly in both EM0 and K-12 JM105 diassociated mice compared with the control C5 infected group. No significant difference was observed between the two groups of $E$ coli associated mice.

In surviving JM105 or EM0 monoassociated C5 infected mice at day 58 after infection, the $\mathrm{Si} 3$ and caecal $\mathrm{C} 5$ population, and tissue translocation of C5 were determined (table 3 ). The intestinal and caecal population level of $\mathrm{C} 5$ was significantly lower in the EM0 associated mice group than in JM105 associated mice. In contrast, the translocation rate of C5 was identical for both groups of $E$ coli associated mice. When examining the level of $E$ coli in the faeces of gnotobiotic C5 infected mice from day 5 to day 58 after C5 infection, we found that the populations of $E$ coli remained at a similarly high level, which varied from $9.2(0.1)$ on day 5 to $8.8(0.2) \log 10 \mathrm{cfu} / \mathrm{g}$ of faeces on day 58 for the EM0 monoassociated C5 infected group. In the case of the JM105 monoassociated C5 infected group, populations of $E$ coli decreased from $9.1(0.2)$ on day 5 to $8.2(0.4) \log 10 \mathrm{cfu} / \mathrm{g}$ of faeces on day 58 .

EFFECT OF E COLI STRAINS ON THE INTESTINAL POPULATION LEVEL OF $S$ TYPHIMURIUM C5 IN INFECTED CONVENTIONAL C3H/HE/OUJCO MICE To determine if the decrease in C5 excretion observed in JM105 and EM0 monoassociated C5 infected germfree mice developed in the presence of a resident microflora, we used three groups of six conventional $\mathrm{C} 3 \mathrm{H} / \mathrm{He} / \mathrm{Oujco}$ mice. Concomitantly with infection with $S$ typhimurium $\mathrm{C} 5\left(1 \times 10^{8} \mathrm{cfu} / \mathrm{mouse}\right)$, conventional mice were orally inoculated daily with one of the $E$ coli strains $\left(1 \times 10^{8} \mathrm{cfu} /\right.$ day/mouse $)$ or LB broth for the control group. Faeces were collected one, four, and seven days after infection. Figure 3 shows that the level of viable C5 bacteria in faeces was not significantly different in faeces of $E$ coli treated C5 infected groups compared with the untreated control C5 infected group. This result demonstrated that in contrast with the germfree situation, $E$ coli strains JM105 and EM0 did not decrease Salmonella excretion in conventional mice.

E COLI STRAINS DO NOT EXPRESS ANTIBACTERIAL ACTIVITY AGAINST $S$ TYPHIMURIUM IN VITRO Enterobacteriaceae strains exert inhibitory activities to closely related bacteria by producing either microcins or colicins. ${ }^{10}$ We have previously reported that Lactobacillus casei GG and L johnsonii Lal strains produced an antibacterial substance that was active in vitro against

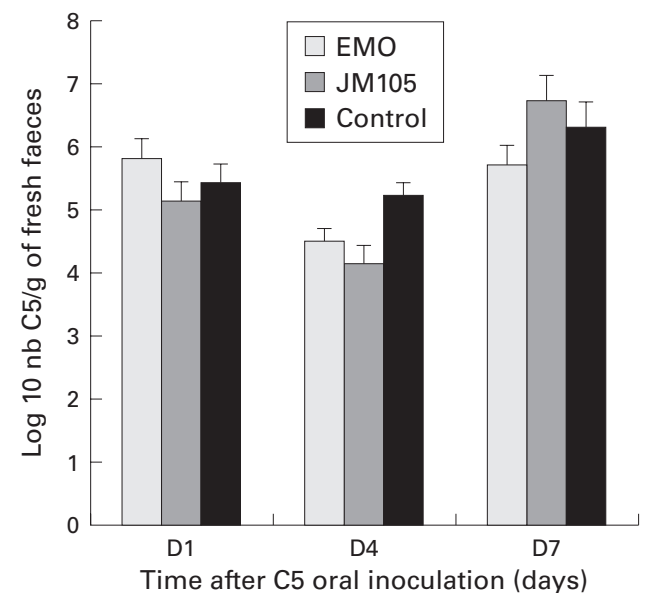

Figure 3 Faecal excretion of $S$ typhimurium $C 5$ from conventional mice treated daily with $E$ coli strains EMO and $7 M 105$, after C5 oral infection. Control and treated mice were infected with a single dose of $S$ typhimurium $C 5$ $\left(1 \times 10^{8}\right.$ cfu/mouse $)$ on day 0 . The treatment consisted of 0.2 $\mathrm{ml}$ of $\mathrm{LB}$ broth (control) or $E$ coli culture $\left(2 \times 10^{8}\right.$ cfulmouse) and was given on day 0 and then daily for seven days after infection. Infection and treatment were achieved using a gastric probe. 
Salmonella..$^{204142}$ These two Lactobacillus strains, once established in the gastrointestinal tract of germfree mice, can protect them against $S$ typhimurium infection and accelerate faecal elimination of Salmonella from the gut of conventional mice treated with these bacterial cultures. ${ }^{20}{ }^{42}$ We investigated if the $E$ coli strains EM0 and JM105 could produce antimicrobial substances by two methods. Firstly, co-culture of $E$ coli EM0 with $S$ typhimurium $\mathrm{C} 5$ in LB showed no inhibition of Salmonella growth. The inoculum of $7 \times 10^{7} \mathrm{cfu} / \mathrm{ml}$ of each strain grew simultaneously and reached the level of $4 \times 10^{8}$ and $6 \times 10^{8}(\log 10$ number of $\mathrm{cfu} / \mathrm{ml})$ for C5 and EM0, respectively, after five hours of culture and $3 \times 10^{8}$ for the two strains after 24 hours of culture. The same growth curve as Salmonella was obtained with $E$ coli JM105. Growth of C5 co-cultured with $E$ coli was not different from growth of C 5 alone in LB broth. Moreover, using the method described by Portrait and colleagues, ${ }^{11}$ it was observed that these two strains did not produce colicin, which is active against $S$ typhimurium C5 (V Portrait, personal communication).

We further investigated if $E$ coli EM0 or JM105 could prevent invasion of $S$ typhimurium $\mathrm{C} 5$ within cultured Caco-2/TC7 cells. For EM0 strain, the inhibition assay of C5 cell invasion was conducted in the presence of dextran 4 for osmotic protection against the pore forming lesions induced by the $E$ coli EM0 haemolysin. ${ }^{39}$ Under these experimental conditions, $E$ coli EM0 haemolysin induced $\mathrm{LDH}$ release of cells was strongly reduced $(10 \%$ of $\mathrm{LDH}$ release versus $100 \%$ in control conditions). In the presence of dextran 4, penetration of $S$ typhimurium C5 within Caco-2/TC7 cells was identical to that obtained in control conditions: 6.7 (0.1) (mean (SEM) $\log 10$ $\mathrm{cfu} / \mathrm{ml}$ for seven trials). The results show that none of the E coli strains (EM0 and JM105) exerted an inhibitory effect against invasion of C5 within Caco-2/TC7 cells. The level of C5 invasion was $6.6(0.1)$ and $6.6(0.2)$, respectively, in the presence of JM105 and EM0.

\section{Discussion}

Our results showed that virulent and nonvirulent $E$ coli strains established in the intestine of germfree mice exerted a protective effect against Salmonella infection. In contrast, no protective effect was found in the conventional mouse model, suggesting that the resident microflora by itself exerts a protective activity and does not allow the display of the protective activity exerted by $E$ coli. These results are different from those recently reported by us showing that the $L$ casei $\mathrm{GG}$ and L johnsonii Lal strains established in the gut of germfree mice delayed the mortality of mice orally infected with $S$ typhimurium. In the conventional mouse model, elimination of Salmonella from the gut was accelerated in groups treated daily with the GG or Lal cultures ${ }^{20} 42$ compared with the control group. These Lactobacillus strains produced an antibacterial substance(s) which was active in vitro against Salmonella. ${ }^{41-43}$ However, the mechanism by which these Lactobacillus exerted a protective effect in vivo against bacterial infection has not yet been elucidated. It has been reported that some $E$ coli strains secrete antimicrobial substances termed microcins and colicins which are active against Gram negative bacteria $^{10}$ such as $S$ typhimurium. ${ }^{11}$ Barrow et al showed that some strains of Enterobacteriaceae such as E coli, Citrobacter, Klebsiella, and Salmonella can induce growth suppression of their isogenic antibiotic resistant mutants in early stationary phase LB broth cultures. ${ }^{8}$ This taxon specific inhibition was not related to lack of nutrients and was not the result of lysogenic bacteriophage or bacteriocin activity as the strains were isogenic. ${ }^{7}$ It was suggested that the inhibition was supported by a diffusible but labile chemical factor. When examining if the EM0 and JM105 strains produced an antimicrobial substance(s) active in vitro against $S$ typhimurium, we found that there was no inhibitory activity of the two $E$ coli strains in the co-culture test and diffusion test. As a consequence, we propose that the protective effect developed by these $E$ coli in monoassociated animals could be due to mechanisms other than production of an inhibitory substance.

The protective effect induced by the in vivo established $E$ coli in germfree mice could be related to occupancy of Salmonella attachment sites as attachment is a prerequisite step before invasion. Indeed, we observed that the two $E$ coli strains efficiently colonised the gastrointestinal tract of germfree mice. As a consequence, the established $E$ coli could form an efficient biofilm of bacteria protecting the intestinal epithelium against attachment of $S$ typhimurium, thus reducing the invasion step. However, our results showed that the number of $E$ coli associated with the intestinal mucosa was 100 times lower than the number of $E$ coli in the luminal contents, indicating that there is no attachment of the bacteria to the intestinal wall itself. ${ }^{12}{ }^{44} E$ coli detected on the washed intestinal wall probably corresponded to the bacteria embedded in the mucus layer, as observed by others. ${ }^{45}$ Moreover, using a cellular model of human enterocyte-like Caco2/TC7 cells which could be infected by $S$ typhimurium, we found that the two $E$ coli strains had no effect on the invasion capacity of $S$ typhimurium. The protective effect of $E$ coli strains cannot be explained by competition for the invasion sites of $S$ typhimurium.

$E$ coli $\mathrm{EM} 0$ was described as a non-virulent strain as it was recovered from a healthy human donor and has been administered to newborns. ${ }^{13}$ In this study, we showed that EM0 had the genes of two virulence factors (haemolysin and $\mathrm{CNF}$ ) whereas $E$ coli $\mathrm{K}-12$ JM105 does not. However, in our experiments, no adverse effect was observed in germfree mice colonised by this strain, as already shown by other authors in germfree piglets and in mice. ${ }^{9} 1322$ The insertion sites of these toxins could also be species dependent and absent in the intestine of $\mathrm{C} 3 \mathrm{H} / \mathrm{He} / \mathrm{Ouj}$ co mice. There is probably no direct interaction in situ between bacteria and enterocytes which would prevent the effect of haemolysin or CNF, since as mentioned above, the two $E$ coli strains do not adhere to the 
mucosa. Interestingly, it has been shown previously that $6-22 \%$ of faecal $E$ coli strains from healthy donors have haemolytic activity ${ }^{33} 46$ without producing pathology in the donors.

Another mechanism usually attributed to probiotics or to bacterial interactions in vivo is competition for nutrient sources. The following results obtained in chickens ${ }^{7}{ }^{48}$ and pigs ${ }^{45}$ show a protective effect against Salmonella intestinal colonisation by previous oral inoculation (one day before) of an avirulent mutant strain of Salmonella. As they observed it in vitro, the inhibitory effect appears to work across the serovar boundary but is more efficient with antibiotic resistant isogenic strains. ${ }^{45} 48$ The mechanism involved is related to competition for nutrients or electron receptor as resistance obtained is nonimmunological and colonisation by the second bacteria is partially or totally reduced $^{48}$ depending on the mutation of the first strain. Our results showed that mice were protected against clinical disease despite the absence of inhibition of colonisation of Salmonella except that there was a significant delay in the establishment of C5 during the two first days after C5 oral inoculation. This delay may be the result of adaptation of the Salmonella strain to growth conditions in the presence of $E$ coli but competition does not lead to elimination of the strain. Filho-Lima et al showed recently that EM0 associated to probiotics ( $L$ acidophilus and Saccharomyces boulardii) was necessary to intestinal elimination of an antibiotic resistant mutant of $S$ flexneri but had no effect on intestinal levels of $S$ enteritidis subspecies typhimurium. ${ }^{22}$

Our results showed protection against systemic infection and lower contamination at remote sites such as the liver and spleen without inhibition of intestinal colonisation. These results are similar to those of Barrow et al (Prevention of salmonellosis in gnotobiotic pigs by precolonisation with avirulent Salmonella strains. "Salmonella and Salmonellosis". Proceedings of Ploufragan, 20-22 May 1997:519-20). They showed a protective effect against $S$ typhimurium infection by inoculating gnotobiotic pigs with an avirulent strain of $S$ infantis. Gut colonisation by $S$ typhimurium was delayed for five days in pretreated animals which survived to oral infection. In these surviving pigs, translocation rates of $S$ typhimurium in MLN, liver, and spleen were decreased significantly as we observed in surviving mice pretreated with $E$ coli (tables 3, 4). Diminution of C5 translocation rate observed here in the MLN could be a consequence of diminution of the intestinal colonisation rate in situ, as Berg and Owens described in conventional mice that the level of translocation to the MLN is related to intestinal levels greater than $10^{8} / \mathrm{g}$. ${ }^{49}$ Diminution of Salmonella at remote sites (liver and spleen) suggests an immunological mechanism. Rapid intestinal colonisation of $E$ coli one week before infection and delay in $S$ typhimurium establishment could allow progressive development of an immunological mechanism of defence. We showed that both EM0 and
JM105 strains translocated from the gastrointestinal tract to the MLN, as found previously by others for indigenous $E$ coli strains in mice $^{5051}$ and piglets. ${ }^{45}$ The clinical significance of translocation of indigenous bacteria and its role in priming the host immune response to improve host defences against overt or opportunistic pathogen(s) is not yet known. ${ }^{50}$ Some authors have reported that $E$ coli participates in the establishment of the population of $\operatorname{IgA}$ plasmocytes in the lamina propria in adult germfree mice, in suckling mice, ${ }^{53}$ and in germfree piglets ${ }^{52}$ to the level obtained in conventional animals. $E$ coli EM0 has several immunological properties whereas those of $E$ coli $\mathrm{K}-12$ have not yet been well studied. In a germfree mice model, ${ }^{25}$ EM0 stimulated secretion of the cytokines interleukin (IL)-1 and IL- 6 by peritoneal macrophages, to the level observed in conventional mice and cytokine production of bone marrow derived macrophages indicating an effect on macrophage precursors. ${ }^{24}$ Other strains of $E$ coli had a similar effect in germfree mice exposed to these strains: stimulation of IL- 6 and tumour necrosis factor (TNF).$^{54}$ Production of TNF- $\alpha$ was also stimulated by the EM0 strain in gnotobiotic mice. ${ }^{25}$ This cytokine in conjunction with interferon $\gamma$ are the main cytokines implicated in the first steps of Salmonella infection..$^{55}$ As a consequence, it can be hypothesised that concerning infection of $\mathrm{C} 3 \mathrm{H} / \mathrm{He} / \mathrm{Oujco}$ mice by $S$ typhimurium, the presence of an established $E$ coli in vivo could stimulate a non-specific immunological response.

Further experiments are required to establish the mechanism by which these two virulent and avirulent $E$ coli strains directly affect $S$ typhimurium pathogenicity. In particular, the immunological aspects of the protective role of $E$ coli should be studied.

We thank V Portrait for colicin determination, C Sandré for revision and council in redaction, and $M$ Métioui for his revision of the English language of the manuscript. J Guignot is l'Education Nationale, de la Recherche et de la Technologie (MENRT).

1 Raibaud P. Main unsolved problems in human gastrointestinal tract microecology. In: Heidt P, Vossen J, Rusch V, eds. Microecology and therapy. Herborn-Dill, Germany: Institut für Mikroökologie, 1996:1-9.

2 Hentges G. Role of the intestinal microflora in host defense against infection. In: Hendges D, ed. Human intestinal microflora in health and disease. New York: Academic Press, 1983:311-31.

3 Benno Y, Sawada K, Mitsuoka T. The intestinal microflora of infants: composition of fecal flora in breast-fed and of infants: composition of fecal flora in breast-fed
bottle-fed infants. Microbiol Immunol 1984;28:975-86.

4 Stark P1, Lee A. The microbial ecology of the large bowel of breast-fed and formula-fed infants during the first year of life. $\mathcal{F}$ Med Microbiol 1982;15:189-203.

5 Yoshioka H, Iseki K, Fujita K. Development and differences of intestinal flora in the neonatal period in breast-fed and bottle-fed infants. Pediatrics 1983;72:317-21

6 Cooperstock M, Zedd A. Intestinal flora of infants. In: Hentges DJ, ed. Human intestinal microflora in health and disease. New York: Academic Press, 1983:79-99.

7 Barrow P, Tucker J, Simpson J. Inhibition of colonization of the chicken alimentary tract with Salmonella typhimurium gram-negative facultatively anaerobic bacteria. Epidemiol Infect 1987;98:311-22.

8 Barrow P, Lovell M, Barber L. Growth suppression in earlystationary-phase nutrient broth cultures of Salmonella typhimurium and Escherichia coli is genus specific and not reguimurium and Escherichia coli is genus specific and
lated by sigma S. F Bacteriol 1996;1 78:3072-6.

9 lated by sigma S. F Bacteriol 1996;178:3072-6. Duval-Iflah Y, Rabaud P, Rousseau M. Antagonisms
among isogenic strains of Escherichia coli in the digestive among isogenic strains of Escherichia coli in the digestive
tracts of gnotobiotic mice. Infect Immun 1981;34:957-69.

10 Baquero F, Moreno F. The microcins. FEMS Microbiol Lett 1984;23:117-24. 
11 Portrait V, Gendron-Gaillard S, Cottenceau G, et al. Inhibition of pathogenic Salmonella enteritidis growth mediated by
Escherichia coli microcin J25 producing strains. Can 7 Escherichia coli microcin

12 Chappuis JP, Duval-Iflah Y, Ducluzeau R, et al. Resistance of gnotobiotic large white and Chinese piglets to in vivo attachment of a K88ab enterotoxigenic Escherichia coli strain. Reprod Nutr Dev 1985;25:49-60.

13 Duval-Iflah Y, Chappuis JP, Ducluzeau R, et al. Intraspecific interactions between Escherichia coli strains in human newborns and in gnotobiotic mice and piglets. Prog Food Nutr Sci $1983 ; 7: 107-16$

14 Barrow P, Tucker J. Inhibition of colonization of the chicken caecum with Salmonella typhimurium by pre-treatment with strains of Escherichia coli. $\mathcal{F}$ Hyg (Lond) 1986;96:161-9.

15 Finlay B. Molecular and cellular mechanisms of Salmonella pathogenesis. Curr Top Microbiol Immunol 1994;192:16385 .

16 Carter P, Collins $\mathrm{F}$. The route of enteric infection in normal mice. F Exp Med 1974;139:1189-203.

17 Hohmann A, Schmidt G, Rowley D. Intestinal colonization and virulence of Salmonella in mice. Infect Immun 1978;22: 763-70.

18 Jones B, Ghori N, Falkow S. Salmonella typhimurium initiates murine infection by penetrating and destroying the specialized epithelial $M$ cells of the Peyer's patches. $\mathcal{F}$ Exp Med 1994;180:15-23.

19 Plant J, Glynn A. Natural resistance to Salmonella infection delayed hypersensitivity and Ir genes in different strains of mice. Nature 1974;248:345-7.

20 Hudault S, Lievin V, Bernet-Camard M, et al. Antagonistic activity exerted in vitro and in vivo by Lactobacillus case (strain GG) against Salmonella typhimurium C5 infection. Appl Environ Microbiol 1997;63:513-18.

21 Rastegar Lari A, Gold F, Borderon J, et al. Implantation and in vivo antagonistic effects of antibiotic-susceptible $E s$ cherichia coli strains administered to premature newborns. Biol Neonate 1990;58:73-8.

22 Filho-Lima J, Vieira E, Nicoli J. Antagonistic effect of Lactobacillus acidophilus, Saccharomyces boulardii, and Escherichic bacillus acidophilus, Saccharomyces boulardii, and Escherichia coli combinations against experimental infections with Shigella flexneri and Salmonella enteritidis subsp. typhimu-

23 Gaboriau-Routhiau V, Moreau MC. Gut flora allows recov3 Gaboriau-Routhiau V, Moreau MC. Gut flora allows recovery of oral tolerance to ovalbumin in mice after transient breakdown mediated by cholera toxin or Escherichic
heat-labile enterotoxin. Pediatr Res 1996;39:625-9.

24 Nicaise P, Gleizes A, Forestier F, et al. The influence of $E$. coli implantation in axenic mice on cytokine production by peritoneal and bone marrow-derived macrophages. Cytokine 1995;7:713-19.

25 Nicaise P, Gleizes A, Forestier F, et al. Influence of intestinal bacterial flora on cytokine (IL-1, IL-6 and TNF-alpha) production by mouse peritoneal macrophages. Eur Cytokine Netw 1993;4:133-8.

26 Finlay B, Falkow S. Salmonella interactions with polarized human intestinal Caco-2 epithelial cells. $\mathcal{F}$ Infect Dis 1990 162:1096-106.

27 Yanisch-Perron C, Vieira J, Messing J. Improved M13 phage cloning vectors and host strains: nucleotide sequences of the M13mp18 and pUC19 vectors. Gene 1985;33:103-19.

28 Sambrook J, Fritsch E, Maniatis T. Molecular cloning: A laboratory manual. In: Harbor NECS, ed. New York: Laboratory Press, 1989: A.10.

29 Pardon P, Popoff M, Coynault C, et al. Virulence-associated plasmids of Salmonella serotype Typhimurium in experimen$47-60$.

30 Elliott S, Srinivas S, Albert M, et al. Characterization of the roles of hemolysin and other toxins in enteropathy caused by alpha-hemolytic Escherichia coli linked to human diarrhea. Infect Immun 1998;66:2040-51.

31 Blum G, Falbo V, Caprioli A, et al. Gene clusters encoding the cytotoxic necrotizing factor type 1, Prs-fimbriae and alpha-hemolysin form the pathogenicity island II of the uropathogenic Escherichia coli strain J96. FEMS Microbiol Lett 1995;126:189-95.

32 Peres S, Marches O, Daigle F, et al. A new cytolethal distending toxin (CDT) from Escherichia coli producing
$\mathrm{CNF} 2$ blocks HeLa cell division in $\mathrm{G} 2 / \mathrm{M}$ phase. Mol Microbiol 1997;24:1095-107.

33 Beutin L. The different hemolysins of Escherichia coli. Med Microbiol Immunol 1991;180:167-82.
34 De Rycke J, Guillot J, Boivin R. Cytotoxins in nonenterotoxigenic strains of Escherichia coli isolated from feces of diarrheic calves. Vet Microbiol 1987;15:137-50

35 Chantret I, Rodolosse A, Barbat A, et al. Differential expression of sucrase-isomaltase in clones isolated from early and late passages of the cell line Caco-2: evidence for glucosedependent negative regulation. F Cell Sci 1994;107:213-25.

36 Pinto M, Robine-Leon S, Appay M, et al. Enterocyte-like differentiation and polarization of the human colon carcinoma cell line Caco-2 in culture. Biol Cell 1983;47: 323-30.

37 Fogh J, Fogh J, Orfeo T. One hundred and twenty-seven cultured human tumor cell lines producing tumors in nude mice. F Natl Cancer Inst 1977;59:221-6.

38 Bernet MF, Brassart D, Neeser J, et al. Lactobacillus acidophilus LA 1 binds to cultured human intestinal cell lines and inhibits cell attachment and cell invasion by enterovirulent bacteria. Gut 1994;35:483-9.

39 Moayeri $M$, Welch R. Effects of temperature, time, and toxin concentration on lesion formation by the Escherichia coli hemolysin. Infect Immun 1994;62:4124-34.

40 Schwartz D. Méthodes stastistiques à l'usage des médecins et des biologistes. Paris: Flammarion Médecine et Sciences, 1990: 93-100.

41 Silva $\mathrm{M}$, Jacobus $\mathrm{N}$, Deneke $\mathrm{C}$, et al. Antimicrobial substance from a human Lactobacillus strain. Antimicrob Agents Chemother 1987;31:1231-3.

42 Bernet-Camard M, Lievin V, Brassart D, et al. The human Lactobacillus acidophilus strain LA1 secretes a nonbacteriocin antibacterial substance(s) active in vitro and in vivo. Appl Environ Microbiol 1997;63:2747-53.

43 Coconnier M, Lievin V, Bernet-Camard M, et al. Antibacterial effect of the adhering human Lactobacillus acidophilus strain LB. Antimicrob Agents Chemother 1997;41:1046-52.

44 Hautefort I, Fléchon B, Degrouard J, et al. Adhesion to the digestive mucosa is not sufficient for durable persistence of different Lactobacillus fermentum strains in the digestive different Lactobacillus fermentum strains in the diges

45 Lovell M, Barrow P. Intestinal colonisation of gnotobiotic pigs by Salmonella organisms: interaction between isogenic and unrelated strains. F Med Microbiol 1999;48:907-16.

46 Opal S, Cross A, Gemski P, et al. Aerobactin and alpha-hemolysin as virulence determinants in Escherichia coli isolated from human blood, urine, and stool. F Infect Dis 1990;161:794-6.

47 Berchieri A, Barrow PA. Further studies on the inhibition of colonization of the chicken alimentary tract with Salmonella typhimurium by pre-colonization with an avirulent mutant. Epidemiol Infect 1990;104:427-41.

48 Zhang-Barber L, Turner A, Martin G, et al. Influence of genes encoding proton-translocating enzymes on suppression of Salmonella typhimurium growth and colonization. $\mathcal{f}$ Bacteriol 1997;179:7186-90.

49 Berg R, Owens W. Inhibition of translocation of viable Escherichia coli from the gastrointestinal tract of mice by bacterial antagonism. Infect Immun 1979;25:820-7.

50 Berg R. Bacterial translocation from the gastrointestinal tract. Trends Microbiol 1995;3:149-54.

51 Moreau MC, Huldault S, Bridonneau C. Systemic antibody response to ovalbumin in gnotobiotic $\mathrm{C} 3 \mathrm{H} / \mathrm{HeJ}$ mice associated with Bifidobacterium bifidum or Escherichia coli. In: Heidt P, Vossen I, Rusch V, eds. Microecology and therapy, vol. 20. Herborn-Dill, Germany: institut für Mikroökologie, vol. 20. Herborn

52 Mandel L, Trebichavsky I, Splichal I, et al. Stimulation of intestinal immune cells by $E$. coli in gnotobiotics piglets. In: Mestecky J, ed. Advances in mucosal immunity. New York: Plenum Press, 1995:463-4

53 Moreau M, Ducluzeau R, Guy-Grand D, et al. Increase in the population of duodenal immunoglobulin A plasmocytes in axenic mice associated with different living or dead bacterial strains of intestinal origin. Infect Immun 1978;21: 532-9.

54 Dalhgren U, Midtvedt T, Tarkowski A. Transient appearance of circulating interleukin- 6 and tumor necrosis factor in germfree $\mathrm{C} 3 \mathrm{H} / \mathrm{Hej}$ and $\mathrm{C} 3 \mathrm{H} / \mathrm{HEN}$ mice upon intestinal exposure to E. coli. In: Mestecky J, ed. Advances in mucosal exposure to E. coli. In: Mestecky J, ed. Advances in
immunity. New York: Plenum Press, 1995:459-62.

55 Pie S, Truffa-Bachi P, Pla M, et al. Th1 response in Salmonella typhimurium-infected mice with a high or low rate of bacterial clearance. Infect Immun 1997;65:4509-14. <th;3> 